\title{
NGO Visit to Vietnam, 14-21 May 1991 Observations and Comments
}

\section{Introduction}

A team of six representatives from non-governmental organizations (NGOs) in the United States, Canada and Australia visited Vietnam from 14 to 21 May 1991, to assess the situation of people who have returned under the voluntary repatriation program established by the Comprehensive Plan of Action (CPA) for Indochinese refugees.

The visit took place following the May 1991 meeting of the Steering Committee of the Comprehensive Plan of Action in which governments made a renewed and stronger commitment to the plan.

The team visited Bangkok (Phanat Nikhom), Hanoi, Hai Phong, Hong Gai in the province of Quang Ninh and Ho Chi Minh City, with one representative going to visit Kuala Lumpur and four visiting the refugee camps in Hong Kong.

The team is grateful for the assistance provided by UNHCR for arranging our program; to the various Ministries of the Government of the Socialist Republic of Vietnam (SRV) for their hospitality and briefings; and to the Peoples Committees in Hanoi, Hai Phong, Quang Ninh and Ho Chi Minh City for their hospitality and assistance. In particular, the team thanks all the returnees who spontaneously granted us interviews and answered our questions.

Those among the team who had previously visited Vietnam, remarked how they were surprised and impressed with the considerable progress the country was making toward becoming a more open society.

We sensed a strong desire amongst the people to see further progress towards a free and open society. Private entrepreneurship is vigorous and there is evidence of economic buoy-

\section{Those among the team}

\section{who had previously visited}

Vietnam, remarked how they

were surprised and impressed

with the considerable progress

\section{the country was making}

toward becoming a

more open society

ancy that is nurturing the increase in personal freedom.

We experienced unhindered access to the people with whom we wished to talk and freedom to ask any questions with or without the presence of government representatives. On several occasions we selected returnees and met with them without the presence of either government or UNHRC officials.

\section{Departures}

In our conversations with the returnees we heard that people had left Vietnam for a variety of reasons, none of which were political persecution.

\section{Screening}

Most of the returnees we interviewed said they were not aware of the screening process before their departures. After learning of the screening process and conditions necessary to be granted refugee status, many did not think they had a sufficient claim to be "screened in" and thus chose to return to Vietnam before screening.

\section{Returning}

In our interviews with returnees and discussions with a variety of sources (international NGO staff, diplomats, journalists, European Community (E.C.) and UNHCR officials) weheard no evidence that returnees suffer harassment, maltreatment or discrimination on return.

We have concluded that UNHCR and SRV are complying in good faith with the terms of the Memorandum of Understanding between SRV and UNHCR (13 December 1988) which provides for the voluntary return from countries of first asylum in conditions of safety and dignity.

The departure of several family groups or groups of close friends appear to have been organized by the head of the household or a "leader" within the group. To facilitate further voluntary return, it is important that no action be taken by Vietnamese authorities against such family group organizers of illegal departures who have no previous criminal record.

Similarly, voluntary return will be encouraged by consistent and generous restoration of confiscated property to returning previous owners.

\section{Monitoring}

It is clear that there is an informal and effective network for communication in Vietnam and with the international Vietnamese refugee community. News travels fast and travels with ease to all parts of the world.

Monitoring occurs in this context and must be seen in this context. Not all returnees are visited on a systematic and regular basis but rather on a random basis.

The increasing presence of international NGO staff in both urban and ruralareascontributes to the increased 
flow of information and thus enhances the confidence in the monitoring process.

Given available resources, we are satisfied that UNHCR is adequately fulfilling its monitoring responsibilities in Vietnam.

\section{Resources}

We regret that CPA donor governments have been slow in making their pledged contributions for 1991. The result is that returnees have had to wait for up to three months for their first quarterly payment of their return assistance. This is an unacceptable delay considering that these people, by-and-large, return with nothing.

Payment to returnees must be made promptly or the process is put at risk. Donorgovernments must ensure that necessary funds are available as required.

As numbers increase it is incumbent on governments to make available the necessary resources to the UNHCR in a timely manner to ensure payment for all aspects of the plan is forthcoming.

Weexpressappreciation for the U.S. Government's speedy contribution to the CPA, but urge the U.S. to revise its policies to allow its contributions to be spent in Vietnam.

\section{European Community Program}

We were impressed with the sense of urgency theProgram Director showed in discussions on progress made in implementing the E.C. program of assistance. We welcome the substantial NGO involvement in the implementation of the program.

We note in particular that 60 percent of available loan funds are for non-returnees thereby indicating that it is not necessary to leave Vietnam and be returned toaccess thesefunds.

\section{Information and Communication}

Ready access to accurate information remains the critical need for effective implementation of the CPA. Rumours inspire people to leave, cause people to fear return and in some cases lead

\section{It is time to allow}

\section{and encourage Vietnam}

\section{to participate fully in the}

\section{international community with}

\section{all the concomitant rights and}

\section{responsibilities of states with}

\section{progressive realization \\ of human rights}

people to choose to return. Rumours hinder a speedy and fair process.

All interested parties must ensure that accurate and up-to-date information is more readily available.

The communication procedures must be better organized. More resources and greater attention must be applied to this issue both in the camps in countries of asylum (through counselling and other programs), as well as in Vietnam and internationally.

\section{Orderly Departure Program (Family Reunion)}

We met the U.S. Orderly Departure Program interview team in Ho Chi Minh City. It has begun processing at an increased rate. Persons with close relatives in the U.S. (or in similar programs for Australia, Canada and Europe) can seek to immigrate directly from Vietnam. This program is increasingly becoming a viable alternative for eligible persons wishing to leave.

\section{Development}

At the heart of the human tragedy that has seen thousands of Vietnamese leave on unsafe boats in search of a better future is the combination of social, economic and political conditions in Vietnam and the constraints stopping development assistance from the International Monetary Fund (IMF), World Bank and major Western donor governments. It is deeply regrettable that Vietnam's participation in the global economy continues to be hampered because of difficulties in its bilateral relationship with the United States. Vietnam needs and wants development assistance.

It is time to allow and encourage Vietnam to participate fully in the international community with all the concomitant rights and responsibilities of states with progressive realization of human rights. We urge our NGO colleagues to support and advocate the necessary policy changes.

\section{Visits}

We note the openness of the Government of the Socialist Republic of Vietnam to receive additional delegations and we encourage other concerned individuals and groups to visit Vietnam to experience the situation firsthand.

\section{Trust}

In conclusion, we wish to pay tribute to the UNHCR officials we met who are responsiblefor theimplementation of this program. We were impressed by their dedication and integrity, in spite of the difficult circumstances in which they sometimes work.

Webelieve that further cooperation between the UNHCR and NGOs will consolidate the trust that the international community has placed in the UNHCR.

This report was prepared by Le Xuan Khoa, President, Indochina Resource Action Centre, Washington; Burgess Carr, Executive Director, Episcopal Migration Ministries, New York; Dale de Haan, Executive Director, Immigration and Refugee Program, Church World Service, New York; Ralston Deffenbaugh, Lutheran Immigration and Refugee Services, New York; Tom Clark, Coordinator, Interchurch Committee for Refugees, Toronto; and Russell Rollason, Executive Director, Australian Council for Overseas Aid, Canberra. 